\title{
Income Support for the Elderly in Zimbabwe
}

\author{
A.C. Nyanguru \\ Department of Sociology/Social Work \\ National University of Lesotho \\ P.O. Roma 180
}

\section{Abstract}

The low economic status of the elderly has been recognized and yet very little research has been carried out in this area. This paper reports on a study carried out on elderly people aged 60 years and over in Harare and Mutare in Zimbabwe, and villages located $50 \mathrm{~km}$ of these cities.

The main areas of study were the reported cash income and its sources, source of income in an emergency and the respondents' satisfaction with levels of the same. The study showed that slightly less than three-quarters of the rural elderly and slightly more than half of the urban elderly had incomes less than the minimum wage specified then. Urban incomes were higher. Two-fifihs of respondents were unemployed, with an equal number employed mostly in manual and low paying jobs. The majority were selfemployed or in subsistence farming. A large number depended on remittances or charity. There were no significant differences in satisfaction with incomes between the rural and urban elderly inspite of the differences in the same. The policy implications of the findings are discussed briefly. 


\section{Introduction}

Historically, respect for the elderly was a core value in the cultures of the people living in modern Zimbabwe. Older people had a clear role to play within the rural community and the responsibility of local villages to provide for the physical and emotional security of the aged was recognized.

The respect accorded to the elderly in "traditional" Shona and Ndebele societies was based on the prominent position which the elderly occupied in the politico-economic system. Clarke (1977) notes that these societies were gerontocracies in which the elderly wielded considerable power. Their influence was exercised through their control of land, food and cattle.

Kinship systems based upon consanguineal ties facilitated the ahsorption of the elderly within caring networks (Nyanguru and Peil, 1993). However, the urbanization and industrialization of Zimbabwean society, with its concomitant emphasis on the nuclear family, has resulted in a loss of security and prestige for the growing population of the nation's aged.

The institutionalization of the colonial economy, however, eroded the economic position of the elderly. For those people who had been employed in mines, industry, agriculture and in domestic service, no financial security in the form of pensions was provided. They were expected to return to the rural villages when they retired. This was particularly difficult for migrant workers from neighbouring countries like Malawi, Mozambique and Zambia as they did not have rural homes and land rights in Zimbabwe. Most had lost ties with relatives in their country of origin.

As a result of the declining rural economy, the introduction of the Structural Adjustment Programme and the lack of an adequate social security system in Zimbabwe, many of the nation's elderly interviewed in studies were found to be destitute; Hampson, (1982); Brand, (1986), Nyanguru, (1987; 1990), Nyanguru and Peil (1991). Specifically, they were without resources to pay rent or buy food, clothing and other necessities. Many respondents reported that they had no one to look after them and that they slept in the open. 
Most of these studies have not specifically looked at different sources of income for elderly people, how they cope in emergencies and the general satisfaction they have with their income. This paper seeks to address these issues.

\section{METHODOLOGIES}

The data used in this article were collected during surveys among African elderly in Zimbabwe. A total of 540 women and 272 men, aged 60 years and older, living in Harare (the capital city), and Mutare (the country's fifth largest city), and villages within $50 \mathrm{~km}$ of these cities, were interviewed. Four hundred respondents live in urban areas and 412 lived in rural areas.

In Harare, the interviews were carried out in four suburbs. Mbare, which is the oldest of main suburbs, is extremely overcrowded, has old houses and has a large rural bus terminus through which over a million people pass each day; Highfield. which is the second oldest suburb, and the first to have a homeownership scheme as well as a municipal housing scheme; Kambuzuma, which had the first African home-ownership township scheme; and Rugare, which is a suburb exclusively for employees of the National Railways of Zimbabwe.

In Mutare, interviews were conducted in the township of Sakubva. Like Mbare, it is one of the oldest suburbs and has a large rural bus terminus, and houses which are old and overcrowded. Interviews were also conducted in Danganvura Township, which is similar to Highfield, and Marymount, which is similar to Kambuzuma.

Further, the study was conducted in six rural areas around Harare and Mutare. Around Harare, interviews were conducted in Goromonzi and Domboshawa communal lands. Around Mutare. interviews were conducted in Mutasa, Zimunya/Dora, Penhalonga (a small town near Mutare) and Chipenje.

The interviewers were unemployed school leavers from the cities of Harare and Mutare, and were specifically trained for the task. They were assigned sections (both in rural and urban areas) and 
instructed to interview persons over 60 years whom they encountered, but not more than two in a house. A pre-test of the data collection instrument was carried out in a suburb in l harare and a communal area some $45 \mathrm{~km}$ outside Harare.

\section{Results and Discussion}

Table 1:

\% Respondents by reported cash income by urban and rural location

\begin{tabular}{|c|c|c|c|}
\hline$Z \$$ & Urban & Rural & Total \\
\hline $0-50$ & 10.5 & 23.1 & 16.8 \\
\hline $51-100$ & 16.3 & 28.1 & 22.2 \\
\hline $101-150$ & 26.5 & 20.7 & 23.6 \\
\hline $151-300$ & 31.0 & 22.0 & 26.5 \\
\hline $301+$ & 15.7 & 6.1 & 10.9 \\
\hline Total & 100.0 & 100.0 & 100.0 \\
\hline $\mathrm{N}$ & 400 & 412 & 812 \\
\hline
\end{tabular}

The results show that the largest group of the respondents, $26.5 \%$ earn between $Z \$ 151$ - 300 per month. The smallest group, (10.9\%) earn over $Z \$ 301$ per month. Further analysis shows that rural elderly respondents earn less than their urban counterparts.

In fact, $71.8 \%$ and $53.2 \%$ of the rural and urban elderly respectively earn less than $Z \$ 150$ per month. This is the official government minimum wage. The results, therefore, show that slightly less than three-quarters of the elderly and slightly more than half the elderly in rural and urban areas fall below the official minium wage. People who fall below this level, according to government policy are entitled to free medical aid and those who 
are over 60 and also unemployed can apply for public assistance.

Most social services in Zimbabwe, like most developing countries are urban based, yet the majority of our elderly, at least $80 \%$, are to be found in the rural areas (Nyanguru and Peil, 1993); Kaseke (1991). Furthermore, most of the services are of poor quality, inaccessible or non-existent. For instance, most destitute elderly are supposed to be treated free, but there are no medicines in the clinics and hospitals or the clinics are too far from the elderly's home, making them inaccessible. During fieldwork, for instance, we found an elderly woman being carried in a wheelbarrow to the nearest clinic as there was no other form of transport. The elderly are forced to buy medicines from chemist shops. These medicines are very expensive. Hence they cannot afford them and have to go without treatment.

Further analysis of the results show that in urban areas. respondents from Mutare earned the least, with $40.0 \%$ earning less than $Z \$ 50.00$ per month. Respondents from Kambuzuma earned the most, with $39.7 \%$ earning more than $Z \$ 301.00$ per month. This is probably because Mbare, the oldest township in Harare, has a number of destitute elderly who live rough and most are either widows or are unemployed. Von Nidda (1985), Hampson (1982); Nyanguru and Peil (1993); Brand (1986). Kambuzuma, on the other hand, was the first home-ownership scheme for Africans in Harare. To qualify one had to meet certain minimum criteria of income earned. The elderly in this township are affluent, some selfemployed as businessmen and they also have other sources of income from renting out some of their rooms. There is also evidence to suggest that they also get financial assistance from children or spouses.

The results for the rural elderly are very interesting in that Goromonzi has both the highest percentage of elderly who earn less than $Z \$ 50.00$ per month, and those who earn more than $Z \$ 301.00$ per month; $36.8 \%$ and $31.3 \%$ respectively. This might go some way to explain the inequalities which are taking place in rural areas. Goromonzi is a rural area only some $40 \mathrm{~km}$ from Harare. Here, one finds a number of squatters, who have formerly been commercial farmworkers or ex-miners from an Acturus Mine, a gold mine 
owned by Lonrho. These elderly are poor and unemployed, often taking piece jobs from villagers. However, in the same area we find indigenous elderly people who are engaged in some incomegenerating projects, such as rearing chickens or market gardening. Market gardening in the area is very lucrative as the growers have a ready market in Harare.

The results also show that twice as many as the elderly in urban areas than in rural areas earn more than $Z \$ 301.00$ per month. This was probably expected as many jobs in urban areas pay better than those in rural areas.

Table 2: $\quad \%$ Financial status of respondents (assessed) by urban and rural location

\begin{tabular}{|c|c|c|c|}
\hline Status & Urban & Rural & Total \\
\hline Poor & 28.7 & 32.5 & 30.6 \\
\hline Fair & 38.0 & 46.1 & 42.1 \\
\hline Good & 33.3 & 21.4 & 27.3 \\
\hline Total & 100.0 & 100.0 & 100.0 \\
\hline N & 400 & 412 & 812 \\
\hline
\end{tabular}

Interviewers were asked to assess the financial circumstances of the respondents and to place them into three categories, poor, fair and good. The results show that $30.6 \%$ of the respondents were poor; $42.1 \%$ as fair and $27.3 \%$ as good. There were very significant differences between the financial status of urban elderly respondents with their rural counterparts. Urban elderly people had a better financial status than the rural elderly.

A comparison of the economic status of the elderly in developed countries would be useful in this discussion. Shanas et al (1968); Townsend, (1962) and Walker (1981) say that, in Britain, elderly people have been shown to be the largest group in poverty ever since such information was collected systematically. Today, just 
over one in four elderly people have incomes equal or below the poverty line compared to one in twenty of non-elderly people. Altogether, nearly two-thirds of the elderly, comprising 5.1 million people live on the margins of poverty, compared with one-fifth of non-elderly people, Walker (1981). In the U.S.A., Hendricks and Hendricks (1977) say that one in every five elderly people have incomes below the federally established minimum. In Japan, Maeda (1978) reports that nine-tenths of elderly people have incomes in the lower half of the income distribution.

Studies from developing countries have come up with similar results. Tout and Tout (1985) in a study in Belize found that the economic conditions of their sample were very low; $35 \%$ were classified as "extremely poor", with only U.S. \$1.25 per week; $35 \%$ had less than U.S. $\$ 2.50$ per week; $30 \%$ were aided by relatives or friends. Ibrahim (1985) found that income was inversely related to dependency. Where old people existed with most dependency on younger people, those younger people had the least economic resources available to meet the needs of the elders.

A study carried out by the Centre for Social Research in Malta (1982) revealed on examination of home circumstances that only $2.3 \%$ of over 615 were described as "poor" while the situation of $44.5 \%$ was considered "modest", and $9.5 \%$ were even observed to be "well-off". In a study in Barbados, Braithwaite (1986) reports that $31.9 \%$ of the elderly felt that they had serious economic problems, and only $42.9 \%$ stated that they had no financial problems at all.

\section{Sources of Income}

\section{Employment}

Walker (1981) argues that the starting point to explain poverty and the dependent social status of the elderly is the social institutions and processes which distribute resources prior to retirement. This means employment and the labour market, but there are also a wide range of other institutions, for example, building societies, insurance companies and social services, which play an important 
part in differential allocation of resources to young as well as old people. An important determinant of living standards in old age is employment status and socio-economic group prior to retirement, which in part, rests partly on social class of origin. Those with high monies from employment are more likely than others to accumulate savings, property and private pension rights. On the other hand, those in low status jobs are more likely than other groups not only to be lowly paid but also to experience sickness and unemployment.

Many gerontologists have postulated that the elderly, especially elderly women, are the last to be engaged and the first to be retrenched. (Conable, 1986). This is generally to make jobs available to younger and more educated people. Retrenchment of workers has also been recently accelerated due to the introduction of the Economic Structural Adjustment Programme.

Table 3: $\%$ present work of respondent by urban and rural location

\begin{tabular}{|l|c|c|c|}
\hline Employment Status & Urban & Rural & Total \\
\hline None & 37.2 & 10.2 & 23.7 \\
\hline Farm & 4.2 & 71.1 & 37.7 \\
\hline Manual & 26.3 & 8.7 & 17.5 \\
\hline Trade & 27.8 & 8.5 & 18.1 \\
\hline Non manual & 4.5 & 1.5 & 3.0 \\
\hline Total & 100 & 100 & 100 \\
\hline N & 400 & 412 & 812 \\
\hline
\end{tabular}

The results show that $23.7 \%$ of the respondents had no form of employment. $37.7 \%$ were subsistence farmers; $17.5 \%$ were formally employed in manual work; $3 \%$ in non-manual work, while $18.1 \%$ were involved in trade. 
Further analysis shows that the largest group of the urban elderly $(37.2 \%)$ are unemployed and $71.1 \%$ of the rural elderly are subsistence farmers. Slightly less than a third of urban elderly are involved in trade. These could be the elderly in the informal sector. Most studies carried out in the informal sector in Zimbabwe have found an over representation of elderly people in this sector, Brand (1986); Sagomba (1987); Hampson (1982), (1985); Nyanguru and Peil (1993); Nyanguru et al (1994).

For the elderly people who are formally employed, many are in manual work, $26.8 \%$ and $8.5 \%$ for urban and rural elderly respectively. For their age, this work is often very hard and tedious. Only very few people were employed in non-manual work, $3 \%$ of the whole sample. More urban elderly belonged to this category than their rural counterparts.

A comparison with studies carried elsewhere would be useful. A study in Vulcabamba (Valley of old age) by Tout (1989) found that $48.1 \%$ of the elderly were engaged in agricultural pursuits, with $53 \%$ owing their own plot of land. Some 19.3\% gained their livelihood from crafts, sewing or making cigars or cigarettes by hand. A further $20 \%$ were involved in miscellaneous activities such as casual laundering, casual hired labour, or petty selling. Only $12.6 \%$ said they did not work because of their age.

When not working at their main source of livelihood, $65.2 \%$ sought some other activity, mainly to earn a little additional income. Additional activities included breeding domestic animals, birdrearing, growing of medicinal herbs and domestic help.

\section{Remittances}

Another source of economic support or income for the elderly are remittances from children and family members. The results show that $55.7 \%$ of urban elderly people and $62.2 \%$ of rural elderly reported receiving remittances from children and other family members respectively.

The elderly in Marymount had the biggest percentage of income from remittances $(76.9 \%$ ), while Rugare had the least, with $40.8 \%$. The reason for this could be that the elderly in Marymount were 
living and dependent entirely on their children for their livelihood, whereas the elderly in Rugare were international migrants having come from neighbouring countries. Most of these did not have children living with them or from whom they could expect remittances, Nyanguru and Peil (1993).

The elderly in Chipenje in Mutare received more remittances than any other rural elderly $(80 \%)$, whereas the elderly in Domboshava received the least, with $53.3 \%$. The reasons for this are not that apparent, but many of the elderly in Chipenje belong to a certain religious organization (sect) called "Guta Ra Johova" (The city of God). They emphasize in their teaching that children must care for their parents. On the other hand, the children of the elderly, like most other areas usually give very little to parents for various reasons, e.g. some are too young to provide, they are unemployed, etc.

Oberai and Singh (1983) in a study of migration in India looked closely at the ability and willingness of migrants to send remittances to those left at home. Out of 4,700 migrants surveyed, only $55.7 \%$ had ever sent remittances home. Strangely, the number of remittances sent tended to increase according to the distance of migration.

The same authors found out that migrants who leave their own country tend to remit larger sums of money than those who emigrate within the country. On the other hand, migrants to other agricultural regions are as generous with their remittances as migrants to urban areas. The size of the remittances tend to vary according to the family's own basic financial circumstances; poor families do not receive more than rich families. However, in many cases, the remittances to the less-well off although intrinsically low, may constitute the entire income of the home-based group.

Apt (1971) in a study in Ghana found that even though financial obligations to the extended family remained very strong and on the whole such obligations were not resented, yet if all children born to the aged in the survey, "only $35 \%$ had become what their parents regarded as good providers." In a study of elderly people living in urban, rural and commercial farming areas in Zimbabwe, Nyanguru et al (1994) found that only $48 \%$ of the elderly received remittances 
from children and other family members. Tarira (1983) fo similar results in her Mhondor study in Zimbabwe, with $31 \% 0$ rural elderly receiving nothing in remittances.

In another study in 1983 in Potosi in Bolivia, Tout (1989) rep that of the 40 interviewed, 16 stated that they had not work certainly no pension. Another 15 indicated work of peri economic prospects, with replies such as "scraping on the mine (for odd spoiling of metal), "street cook", "works sometim "casual", or "carrying in the markets". In two of the seven c where a marriage still existed with dependent children (6 an respectively), the husbands were still of an age when they $m$ have continued. Working ( 43 and 50 ) but were totally incapacit by lung trouble.

In another case, the husband (aged 55) was incapacitated $t$ extent but was able to do some casual scrabbling on the mine ti his own account in order to help provide for the four depen grand-children living the home.

\section{Other sources of Income}

These sources of income include income from government in form of pensions or public assistance, pensions from for employers, assistance from international and national governmental organizations, churches, clubs and from friends neighbours. Elderly people also get income from begging on streets.

The results show that $24.1 \%$ of urban elderly and $10.7 \%$ of rural elderly reported that they had other sources of getting inc other than from earnings or remittances from children or $c$ family members. The reason why there are more respondents another source of income in urban areas than rural areas is that $r$ of services e.g. social welfare offices are urban based and access to people in urban areas. Again, most elderly people's pligh more likely to get public concern in urban areas than in rural an Again, most rural elderly people do not know their rights and they are entitled to some services like public assistance or medical treatment. Furthermore, more elderly in urban areas 
likely to be entitled to a pension because they are likely to have been formally employed than their rural counterparts. Renting out a room in urban areas is yet another source of income for the elderly. A number of international and national non-governmental organizations also usually help the elderly in kind, but at times in cash. For instance, Help Age International has a programme called adopt-a-granny. In this programme, an elderly person is identified and is "adopted" by a family or an individual person in Europe or North America. Money is sent to benefit this elderly person. The programme is still in its infancy in Zimbabwe, however, church organizations, especially the Salvation Army has helped the elderly in Zimbabwe with cash and other material goods. The Salvation Army has built and runs several old people's homes in the country. Some elderly persons, especially the blind in urban settings, get income by begging on the streets. Most of these people are on public assistance, but they complain that the amount they get from government as public assistance is not enough to meet their daily needs. Hence, they resort to begging. Many of the elderly people are seen being led along the streets by small school going age children.

Further analysis reveals that none of the elderly in Marymount had any other source of income, while the elderly living in Rugare had the biggest percentage, $40.0 \%$, representing another source of income. The reason for this is probably because the elderly in Marymount depend solely on their children and family members for their needs, on the other hand, the elderly in Rugare have been former employees of the National Railways of Zimbabwe and are entitled to a pension. A number were also on public assistance. 
Table 4: \% Respondents' source of income in an emergency

\begin{tabular}{|l|c|c|c|}
\hline Source & Urban & Rural & Total \\
\hline Self & 14.2 & 15.6 & 14.9 \\
\hline Spouse & 6.3 & 13.4 & 9.9 \\
\hline Children & 49.1 & 53.4 & 51.2 \\
\hline Other & 30.4 & 17.6 & 24.0 \\
\hline Total & 100.0 & 100.0 & 100.0 \\
\hline N & 400 & 412 & 812 \\
\hline
\end{tabular}

The respondents were asked who was likely to help them with money in an emergency. Over half, the elderly respondents reported that they would expect to get assistance from their children; a quarter expected to get help from other sources.

These could include friends, churches, clubs, burial societies or money lenders. Slightly over a tenth had some savings, with a tenth getting help from a spouse. Twice as many elderly in rural areas expected to get help from a spouse than their urban counterparts. This is probably because many elderly in urban areas were either single, widowed or divorced. There were also significant differences between the elderly expecting help from other sources. Twice as many urban elderly expected to get help from other sources (friends, churches, etc) than their rural elderly. What is interesting from these results is that elderly parents do not usually get assistance or remittances from their children, yet they put a lot of hope and trust that these very same children should be able to help them in an emergency. 
Table 5:

$\%$ status faction with income by urban and rural location

\begin{tabular}{|l|c|c|c|}
\hline Level & Urban & Rural & Total \\
\hline $1-3$ & 32.2 & 35.8 & 34.0 \\
\hline 4 & 20.8 & 18.5 & 19.7 \\
\hline 5 & 23.9 & 26.8 & 25.3 \\
\hline $6-7$ & 23.1 & 18.9 & 21.0 \\
\hline Total & 100.0 & 100.0 & 100.0 \\
\hline $\mathrm{N}$ & 400 & 412 & 812 \\
\hline
\end{tabular}

The results show that a third of the respondents are dissatisfied with their incomes. There were significant differences between the elderly in rural and urban areas. Slightly less than half of the respondents were somewhat satisfied with their levels of incomes.

Again, the differences between the two groups were insignificant. A fifth of the elderly were very satisfied, more urban elderly falling in this category. This could be because the elderly in urban areas generally earn more than their rural counterparts.

The results are interesting in that there are insignificant differences between the satisfaction of the two groups under study, yet their incomes are significantly different. The reasons for this could be the fact that the standard of living in urban areas is higher than that in rural areas. The elderly in urban areas have to pay rent, buy food, pay for electricity and water and other amenities; items the elderly in rural areas do not have to pay for. It has also been found in the study that more urban elderly are unemployed than their rural counterparts. The majority of the elderly in rural areas are engaged in subsistence farming. This means that they are busy with something rather than just as is likely to be with the case with their urban counterparts. 
Studies on elderly people have found that the elderly enjoy doing work for work itself, even if there is no reward for it. They yearn to be involved in the day to day running of their households and not to be disengaged from the mainstream of society.

\section{Policy Suggestions}

The elderly should be allowed to stay in their jobs as long as they could. Unfortunately, this is against one of the premises of the Economic Structural Programme. However, by keeping their jobs as long as they could, will as long as they could, the elderly will be able to meet their basic needs from their earnings. Work can also enhance their self-esteem and self-worth as human beings in their society. They would feel that they are making a meaningful contribution to their families, communities and society at large.

If the elderly cannot be absorbed into the formal employment sector, they could be encouraged to join the informal sector. Many studies in Zimbabwe as has been mentioned earlier in this discussion, have shown that the elderly are over-represented in this sector. However, this sector is hostile even for young and ablebodied people. There are no amenities like water, shelter, electricity etc. There is also generally police harassment of operators. Zimbabwe needs to put in place positive policies for people to benefit from activities carried out in this sector. The elderly might need soft loans, training and markets for their goods when they start income-generating projects. In short, there is need to empower the elderly.

Zimbabwe should look at the question of pensions for the elderly. The National Insurance Pension Scheme which has been instituted seems to protect those who are already protected, in that it covers those in formal employment. The majority of our elderly are not covered as they are either unemployed or are subsistence farmers. One would suggest that when elderly peasant farmers harvest more than they need for subsistence in any one year, government could buy this produce, which could be used as pension later. Sri Lanka has used this programme. It is also suggested that the amount given as public assistance be raised as this amount 
cannot meet the daily needs of the elderly as recipients.

It is suggested that children or relatives who are looking after elderly people should get tax relief as is done with those who have dependent children. Many children, most studies have shown, would like to care for their elderly parents, but fail to do so because they lack adequate resources.

Lastly, but not least, programmes like those in China, should be put into place where the elderly are involved in activities which benefit the community. These programmes could be the provision of social services for the elderly by the elderly, educational programmes, where the elderly would fundraise with school children and the proceeds would benefit some elderly who are less fortunate than themselves. 


\section{References}

Apt, N.A. (1971) "Socio-economic conditions of the aged in Ghana" in Tout, IC (ed). Elderly Care: A World Perspective. London: Chapman and Hall.

Braithwaite, E.S. (Ed) (1986) The Elderly in Barbados. Barbados: Caribbean, Research and Publications.

Brand, V. (1986) "One dollar workplace: A study of informal sector activities in Magaba, Harare". Journal of Social Development in Africa, I(2):53-74.

Clarke, D. (1977) Economics of African old age subsistence in Rhodesia, Giveru: Mambo Press.

Conable, C.W. (1986) "Conversations in Nairobi: Aging and the Global agenda for women": American Association for International Aging, Washington, D.C.

Hampson, J. (1982) Old age, a study of ageing in Zimbabwe. Gweru:

Mambo Press.

Helpage International (2004) Age and Security, London, Helpage International.

Hendricks, J. and Hendricks, C. (1977) Dimensions of Ageing: Readings, Cambridge, Winthrop Publishers.

Ibrahim, M. (1985) Tradition and Modern Development in Bangladesh

Society. Dhaka: Bangladesh Association for the aged.

Kaseke, E. (1991) "Social work practice in Zimbabwe", Journal of Social Development in Africa, 6(1) 33-45. 
Maeda, (1978) "Aging in Eastern European Society", in Hobman, D. (Ed) The Social Challenge of Ageing. New York: St. Martin's Press.

Malta, Centre for Social Research (1982) A study on the aged, Malta: Social Action Movement.

Mothibe, P. (1996) "Social support systems for the elderly in Lesotho", and M.S.W. dissertation presented to the National University of Lesotho, 1996.

Nyanguru, A.C. (1987) "Residential care for the destitute elderly: A

comparative study of two institutions in Zimbabwe". Journal of Cross-cultural Gerontology, 2(4) 345-58.

(1990) "The quality of life of elderly living in institutions and homes in Zimbabwe". Journal of Social Development in Africa, 5(2): 25-43.

Nyanguru, A.C. (2003) "Income support for the elderly in Lesotho", The African Anthropologist, Journal of Pan African Anthropological Association, Vol. 10(2): 154-179.

Nyanguru, A.C. (2005a) "The rights of the elderly in Lesotho", Journal of Social Development in Africa, Vol. 20(2): 65-86.

Nyanguru, A.C. and Peil, M. (1993) "Housing and the elderly in Zimbabwe". Southern African Journal of Gerontology, 2(1):3-9.

Nyanguru, A.C. Hampson, J. Adamchak, D. and Wilson, A. (1994) "Family Support for the elderly in Zimbabwe", Southern African Journal of Gerontology, 3(1) 22-26. 
Oberai, A. and Singh, H. (1983) Causes and consequences of international

migration: A study in the Indian Punjab, New Delhi, Oxford Liniversity Press.

Sagomba, F. (1987) "Activities of the aged in the informal sector and the aged in the relevance of the disengagement theory", unpublished, Harare: School of Social Work, University of Zimbabwe.

Shanas, W. Townsend, P. Wedderburn, D. Frus, H. Milhoj, P. and Stehouwer, J. (1986) Old People in Three Industrial Societies, Routledge and Kegan Paul.

Tarira, J. (1983) "Helping the aged in their rural environment", BA (SW) dissertation. Harare: School of Social Work, University of Zimbabwe.

The Star, August, 2006.

Tout, K. and Tout, J. (1985) Journey to Latin America. London, HtA.

Tout, K. (1989) Ageing in developing countries. Oxford: Oxford University Press.

Tout, K. (Ed) (1994) Elderly Care: a world perspective. London, Chapman and Hall.

Von Nidda, R. (1985) Need we worry about the elderly? Social Change and development. 1(11): 7-9.

Walker, A. (1981) "Towards a Political economy", Ageing and Society, I(1):73-94. 


\section{(ब) $\odot \Theta$}

This work is licensed under a

Creative Commons

Attribution - NonCommercial - NoDerivs 3.0 License.

To view a copy of the license please see:

http://creativecommons.ora/licenses/bv-nc-nd/3.0/ 